\title{
Efficacy and Adverse Events of Immunotherapy with Checkpoint Inhibitors in Older Patients with Cancer
}

\author{
Yara van Holstein ${ }^{1}$ (D) Ellen Kapiteijn ${ }^{2} \cdot$ Esther Bastiaannet $^{2,3} \cdot$ Frederiek van den Bos $^{4} \cdot$ Johanneke Portielje $^{2}$. \\ Nienke A. de Glas²
}

Published online: 18 July 2019

(c) The Author(s) 2019

\begin{abstract}
The number of older patients with cancer is increasing as a result of the ageing of Western societies. Immune checkpoint inhibitors have improved cancer treatment and are associated with lower rates of treatment-related toxicity compared with chemotherapy in the general population. Nonetheless, immune checkpoint inhibitors have potentially serious immune-related adverse events, which might have a greater impact on older and more vulnerable patients and potentially influence treatment efficacy and quality of life. Previous clinical trials have shown no major increase in immune-related adverse events; however, older patients are underrepresented and relatively healthy in these trials. Observational studies suggest that older and more vulnerable patients may be at a higher risk of immune-related adverse events and early treatment discontinuation. Geriatric assessment could help identify older patients who will benefit from immune checkpoint inhibitors.
\end{abstract}

\section{Key Points}

Previous clinical trials did not show major increases in immune-related adverse events in older patients.

Limited available observational studies suggest that older and more vulnerable patients may be at a higher risk of immune-related adverse events and early treatment discontinuation.

Geriatric assessment could help identify older patients that will benefit from immune checkpoint inhibitors.

Nienke A. de Glas

N.A.de_Glas@lumc.nl

1 Department of Gerontology and Geriatrics, Leiden University Medical Center, Leiden, The Netherlands

2 Department of Medical Oncology, Leiden University Medical Center, PO Box 9600, 2300 RC Leiden, The Netherlands

3 Department of Surgery, Leiden University Medical Center, Leiden, The Netherlands

4 Department of Geriatrics, Utrecht University Medical Center, Leiden, The Netherlands

\section{Introduction}

In recent years, the number of older patients with cancer is strongly increasing as a result of the ageing of Western societies. In the Netherlands, $45 \%$ of patients with melanoma, $68 \%$ of patients with lung cancer and $69 \%$ of patients with urinary tract cancer are aged older than 65 years [1]. Cancer in older patients frequently appears in the context of comorbid diseases, frailty and geriatric problems such as physical or cognitive impairment [2], which has been shown to affect the ability to endure toxic cancer treatments [3]. Previous studies demonstrated that older patients are at increased risk of chemotherapy toxicity [3]. Additionally, the risk of dying from other causes increases with age $[4,5]$, which means that some patients may not have the remaining life expectancy to benefit from anti-cancer therapy. Therefore, it is important to weigh the benefits and risks of anti-cancer treatment in older patients.

In recent years, immunotherapy targeting checkpoint inhibition has improved the treatment of different types of cancer. Immunological checkpoint molecules suppress the attack of tumour-specific $\mathrm{T}$ cells, which usually are an integral part of anti-tumour immunity [6,7]. Some checkpoint inhibitors block the interaction between programmed cell death-1 (PD-1) on T cells and its ligand PD-L1 on cancer cells and myeloid cells $[6,8]$. Others target cytotoxic T-lymphocyte antigen-4 (CTLA-4), which blocks negative signals 
during T-cell interaction with antigen-presenting cells and depletes regulatory $\mathrm{T}$ cells, thereby restoring and enhancing T-cell reactivity $[9,10]$. These drugs are used in an expanding group of tumour types but are most successful in advanced and metastasized melanoma, where progressionfree survival (PFS) and overall survival (OS) have strongly improved [11-14].

However, it is possible that checkpoint inhibitors may be less efficient in older patients because of an ageing immune system (immunosenescence) [6, 7]. The numbers of dendritic cells and CD4+ naive T cells decline while the pool of terminally differentiated CD8+ T cells increases [7, 15]. In addition, the number of circulating and intra-tumoural myeloid-derived suppressor cells increases. Hence, T-cell function may decrease and lead to impaired responsiveness to therapies aiming to boost tumour immunity $[6,16]$. Treatment with checkpoint inhibitors is expensive, costing around 50,000-80,000 euros per treatment [17]. Because checkpoint inhibitors potentially have serious adverse events and are costly, it is essential to determine which patients truly benefit from therapy and at what risk. The aim of this review is to provide a summary of available efficacy data, to provide an overview of the occurrence of adverse events of checkpoint inhibitors in older patients and to evaluate the available evidence on the treatment of these adverse events. We performed an explorative search on PubMed using the following keywords: "Elderly", "Older", "Immune Checkpoint Inhibitors", "Immunotherapy", "Toxicity", and "Immunerelated adverse events". We additionally searched through the references of the publications found and we searched abstracts presented at recent oncology conferences.

\section{Treatment Efficacy of Immune Checkpoint Inhibitors in Older Patients}

\subsection{Melanoma}

Several studies have shown the effectiveness of immune checkpoint inhibitors in melanoma for patients of all ages. In 2018, an update of the Cochrane review was performed with respect to systemic treatments for metastatic cutaneous melanoma [18], which showed that with regard to immune checkpoint inhibitors, anti-PD-1 improved OS compared with chemotherapy, and probably improved PFS. Anti-PD-1 was associated with a better OS and PFS compared with anti-CTLA-4. Anti-CTLA-4 plus chemotherapy probably increased PFS compared with chemotherapy alone, but was not significantly associated with an OS gain. Last, the combination of anti-CTLA-4 plus antiPD-1, as compared with anti-CTLA-4 alone, was associated with better PFS. Patients in this Cochrane review had a mean age of 57.5 years at the time of treatment randomisation, representing a younger population than general patients with melanoma (Table 1).

In the general older patient population, evidence with regard to the efficacy and toxicity of CTLA- 4 inhibitors is lacking. A meta-analysis including patients with melanoma, lung and renal cell cancer suggested that older patients benefit from anti-CTLA-4 therapy in terms of OS with a hazard ratio (HR) of 0.73 [95\% confidence interval (CI) 0.62-0.87; $p<0.001]$ in comparison with the control regimen [8]. For anti-PD- 1 treatment, a retrospective study by Betof et al. showed no difference in OS or PFS in patients with metastatic melanoma, comparing patients aged $\geq 75$ years with younger patients [19]. However, only $20-40 \%$ of patients included in these trials are aged $>65$ years[20], while $45 \%$ of the general melanoma population is aged $>65$ years [1]. The older patients included in these trials are probably not representative for the general population of patients with cancer because of selective inclusion criteria, such as a good performance status, normal hepatic and renal function, and no autoimmune disease. Furthermore, studies have shown that older patients discontinue their treatment more often than younger patients, possibly decreasing effectiveness [21].

\subsection{Non-Small Cell Lung Cancer}

Khan et al. performed a meta-analysis of the available evidence from randomised controlled trials in 2018 comparing anti-PD-1 or PD-L1 therapies and chemotherapy in the treatment of advanced non-small cell lung cancer (NSCLC) [22]. A total of seven randomised controlled trials were selected for inclusion; anti-PD-1 or PD-L1 therapies resulted in a better OS, PFS, and objective response rate in comparison to chemotherapy with pooled HRs of 0.72 (95\% CI $0.63-0.82$; $p<0.00001), 0.84$ (95\% CI 0.72-0.97; $p<0.02$ ) and odds ratio 1.52 (95\% CI 1.08-2.14; $p<0.02$ ), respectively. In subgroup analyses for OS, a significant HR was found in patients aged above 65 years [HR 0.71 (95\% CI 0.56-0.91; $p=0.006)$ ]; however, there was no benefit for patients above 75 years [HR 1.23 (95\% CI 0.61-2.48; $p=0.56)$ ]. For PFS, no significant association was found in subgroup analyses, with an HR of 0.78 (95\% CI $0.57-1.09 ; p=0.14$ for patients over the age of 65 years and 1.25 (95\% CI $0.70-2.22$; $p=0.45$ ) for patients over the age of 75 years, respectively. A systematic review and meta-analysis by Peng et al. showed that immune checkpoint inhibitor combination therapy was significantly associated with prolonged OS in NSCLC [HR 0.80 (95\% CI 0.73-0.88; $p<0.00001$ )], but not in SCLC [HR 0.94 (95\% CI 0.82-1.08; $p=0.40)$ ]. Furthermore, the data suggested a higher efficacy for PD-1 inhibitors than PD-L1 or CTLA-4 inhibitors; however, no specific data for older patients were reported [23]. 
Table 1 Overview of systemic treatments for metastatic cutaneous melanoma [18]

\begin{tabular}{|c|c|c|c|}
\hline Cochrane review & Relative effect (95\% CI) & No. of patients (studies) & $\begin{array}{l}\text { Quality } \\
\text { evidence } \\
\text { (grade) }\end{array}$ \\
\hline \multicolumn{4}{|c|}{ Anti-PD-1 compared with chemotherapy } \\
\hline Overall survival & HR $0.42(0.37-0.48)$ & $418(1)$ & High \\
\hline Progression-free survival & HR $0.49(0.39-0.61)$ & $957(2)$ & Moderate \\
\hline Tumour response & RR $3.42(2.38-4.92)$ & $1367(3)$ & High \\
\hline Toxicity ( $\geq$ G3) & RR 0.55 (0.31-0.97) & $1360(9)$ & Low \\
\hline \multicolumn{4}{|c|}{ Anti-PD-1 compared with anti-CTLA-4 } \\
\hline Overall survival & HR $0.63(0.60-0.66)$ & $764(1)$ & High \\
\hline Progression-free survival & HR $0.54(0.50-0.60)$ & $1465(2)$ & High \\
\hline Tumour response & RR 2.47 (2.01-3.04) & $1465(2)$ & High \\
\hline Toxicity ( $\geq$ G3) & RR $0.70(0.54-0.91)$ & $1465(2)$ & Low \\
\hline \multicolumn{4}{|c|}{ Anti-CTLA-4 + chemotherapy compared with chemotherapy } \\
\hline Overall survival & HR $0.81(0.65-1.01)$ & $1157(2)$ & Low \\
\hline Progression-free survival & HR $0.76(0.69-0.92)$ & $502(1)$ & Moderate \\
\hline Tumour response & RR $1.28(0.92-1.77)$ & $1157(2)$ & Moderate \\
\hline Toxicity $(\geq \mathrm{G} 3)$ & RR 1.69 (1.19-2.42) & $1142(2)$ & Moderate \\
\hline \multicolumn{4}{|c|}{ Anti-CTLA-4 + anti-PD-1 compared with anti-CTLA-4 (overall survival not measured) } \\
\hline Progression-free survival & HR $0.40(0.35-0.46)$ & $738(2)$ & High \\
\hline Tumour response & RR $3.50(2.07-5.92)$ & $738(2)$ & High \\
\hline Toxicity ( $\geq$ G3) & RR 1.57 (0.85-2.92) & $764(2)$ & Low \\
\hline
\end{tabular}

$C I$ confidence interval, $C T L A-4$ cytotoxic T-lymphocyte antigen-4, G3 grade 3, $H R$ hazard ratio, $P D-1$ programmed cell death-1, $R R$ relative risk

\subsection{Bladder and Renal Cell Cancer}

The first breakthrough in cancer therapy for metastatic bladder cancer was in 2016 with the approval of atezolizumab for patients who have disease progression during or following chemotherapy, or have disease progression within 12 months of (neo)adjuvant treatment with chemotherapy [24]. Since then, four additional checkpoint inhibitors have been approved [25]: durvalumab and avelumab (PD-L1 blockade) as well as nivolumab and pembrolizumab (PD-1 blockade). From the five available inhibitors, pembrolizumab is the only drug with level I evidence from a phase III trial specifically in urothelial cancer. An improved OS was seen in the KEYNOTE-045 study [26] with a median OS of 10.3 months as compared with 7.4 months in the chemotherapy arm. There are several ongoing trials in patients with urothelial cancer with immune checkpoint inhibitors; however, specific data for older patients are not yet available [27].

A recent meta-analysis with respect to metastatic renal cell cancer showed an improved survival with an HR of 0.75 (95\% CI $0.66-0.85 ; p<0.001)$ for immunotherapy as firstor second-line therapy compared with standard of care and an improved PFS with an HR of 0.88 (95\% CI 0.80-0.97; $p=0.009$ ) [28]. Unfortunately, no specific data for older patients were presented and those included in the trials are usually not representative of the general older population.

\section{Immune-Related Adverse Events in Older Patients}

It was shown that chemotherapy toxicity occurs more frequently in older patients than younger patients [3]. We hypothesise that, because of an ageing immune system, agerelated comorbidity and decreased functional reserve, older patients might also experience more immune-related toxicities with greater impact owing to hospitalisation. Immune checkpoint inhibitors are responsible for specific inflammatory toxicities by increasing the activity of the immune system. These adverse events are referred to as immune-related adverse events (irAEs). The precise underlying mechanism is unknown. Translational studies in patients with irAEs have shown that T-cell response, antibodies and cytokine responses may all be involved [29]. The majority of irAEs occur within the first 4 months of treatment, but these events can occur at any time during treatment or several months after discontinuation [29, 30].

Nearly all organs can be affected: the skin, gastrointestinal tract, endocrine glands, lung, nervous system, liver, kidney, hematological cells, musculo-articular system, heart and eyes. The spectrum of toxicities seen in CTLA- 4 inhibitors or PD-1/PD-L1 inhibitors is similar, but frequencies differ. In general, CTLA-4 inhibitors have shown more grade 3-4 irAEs than PD-1/PD-L1 inhibitors [20, 30]. In addition, 
the combination of anti-CTLA-4 and PD-1/PD-L1 blockade for metastatic melanoma can cause treatment-related adverse events in $95 \%$ of patients, with grade 3 or higher events in $55 \%$ of patients [31].

With regard to toxicity in older patients, previous randomised trials have rarely studied these outcomes in relation to age. Most evidence is derived from subgroup analyses and cross trial meta-analyses of larger clinical trials. Table 2 summarises the data from trial subgroup analyses, when published.

\subsection{Cytotoxic T-Lymphocyte Antigen-4 Inhibitors: Trial Data}

Previous studies have reported irAEs in $60-86 \%$ of patients of all ages using ipilimumab (CTLA-4 inhibitor). Around $20-41.6 \%$ of patients develop grade 3 and 4 toxicities, depending on dose $[20,30,32]$. The most frequently observed toxicities $(>10 \%)$ are diarrhea, rash, pruritus, fatigue, nausea, vomiting, anorexia and abdominal pain $[20,30]$.

Friedman et al. reported a toxicity analysis of published phase III data in a small group of patients aged older than 80 years treated with different immune checkpoint inhibitors for melanoma. The rate of irAEs and early treatment discontinuation was modestly higher in older patients compared with a younger population. This effect was especially seen in combination therapy $[7,21]$.

\subsection{Programmed Cell Death-1/Programmed Death-Ligand 1 Inhibitors: Trial Data}

For nivolumab, $58-85 \%$ of patients of all ages reported irAEs, of which 7-20\% were grade 3 and 4 toxicities, depending on tumour localisation. For pembrolizumab, $57-80 \%$ of patients reported irAEs, of which $10-26 \%$ were grade 3 and 4 toxicities, depending on dose [20, 30, 32]. The most commonly observed toxicities $(>10 \%)$ are fatigue, rash, pruritus, diarrhoea, nausea and arthralgia [20,30].

The KEYNOTE trials have investigated the efficacy of pembrolizumab in 3991 patients with melanoma, NSCLC, head and neck cancers, urothelial carcinoma and Hodgkin's lymphoma. Forty-six percent of the patients were age $\geq 65$ years and $16 \%$ were age $\geq 75$ years. No overall differences in safety were observed between older and younger patients [33, 34]. This was recently confirmed in an update that was presented at the European Lung Cancer Congress 2019 , in which it was shown that there was no difference in irAEs between patients aged $<75$ and $>75$ years [35].

The Checkmate trials assessed treatment with nivolumab for NSCLC, melanoma and renal carcinoma. In total, 1359 patients were treated with nivolumab, of whom $39 \%$ were aged $\geq 65$ years and $9 \%$ were aged $\geq 75$ years. No overall differences in safety were observed between older and younger patients $[33,36]$. Spigel et al. presented a pooled analysis of 520 patients aged $\geq 70$ years and 108 patients with a baseline Eastern Cooperative Oncology Group (ECOG) performance status of 2, receiving nivolumab for metastatic NSCLC in the Checkmate 153 trial. There was no difference in the incidence of treatmentrelated adverse events, any grade and grade $3-5$, between the older and younger patients and between the patients with ECOG performance status 2 and 0-1 [37].

The US Food and Drug Administration published a subset analysis of the safety of nivolumab in elderly patients. They reviewed 1030 patients in registration trials of lung cancer, renal cancer and melanoma. The data show more reported grade $3-5$ adverse events in patients aged $\geq 70$ years and a trend towards a higher incidence of irAEs requiring treatment with immune-modulating medication in this group. The indications for immune-modulating medication were mostly rash or colitis $[33,38]$.

Herin et al. analysed patients with advanced solid tumours enrolled in 14 immunotherapy phase I/II trials, comparing all included patients aged $\geq 70$ years with patients aged $<70$ years. Median age in the older patient group was 75 years with an ECOG performance status $0-1$. Cumulative incidence of grade 1-2 irAEs was significantly higher in older patients compared with younger patients. The data show a trend towards a higher incidence of grade 3-4 irAEs, occurring in $22 \%$ of older patients vs. $13 \%$ in younger patients. However, the difference was not statistically significant. Median time before the occurrence of a first event was shorter in older patients [39].

The clinical immunotherapy trials included only $20-40 \%$ of patients aged $>65$ years [20]. Therefore, it must be noted that the data are derived from trials including primarily patients below the age of 75 years and with an ECOG performance status of 0-1 or Karnofsky performance status of 80-100, while the general population of older patients with cancer is generally older and has a lower performance status $[9,14,31,32,40-43]$. It is conceivable that more vulnerable older patients with a decreased functional reserve experience more adverse events with a greater impact on quality of life.

\subsection{Population-Based Data}

There have been some previous observational studies in older patients who received immunotherapy that included a population-based sample of older patients, which is more likely to resemble daily clinical practice. Table 3 summarises these studies. For example, Sattar et al. performed a retrospective study on the efficacy and toxicity of ipilimumab, pembrolizumab, and nivolumab including 23 patients aged $\geq 75$ years with a median Charlson comorbidity score of 6.8 . They found no statistically significant 
Table 2 Overview of trial data regarding immune-related adverse events (irAEs) in elderly patients with cancer

\begin{tabular}{|c|c|c|c|c|c|}
\hline Study (first author, year) & No. of patients & Tumour type & Checkpoint inhibitor & $\begin{array}{l}\text { Relevant } \\
\text { outcome }\end{array}$ & Results \\
\hline Friedman, 2016 [21] & $\begin{array}{l}\text { Patients aged } \geq 80 \text { years } \\
N=98\end{array}$ & Melanoma & $\begin{array}{l}\text { Ipilimumab } \\
\text { Nivolumab Pembroli- } \\
\text { zumab } \\
\text { Combination ipili- } \\
\text { mumab + nivolumab }\end{array}$ & irAEs & $\begin{array}{l}\text { Any grade irAEs } \\
\text { Ipilimumab }(n=74): 87.8 \% \\
\text { Anti-PD-1 }(n=24): 87.5 \% \\
\text { Nivolumab + ipilimumab } \\
\quad(n=8): 87.5 \% \\
\text { Grade } 3 \text { or } 4 \text { irAEs } \\
\text { Ipilimumab }(n=74): 29.7 \% \\
\text { Anti-PD-1 }(n=24): 20.8 \% \\
\text { Nivolumab + ipilimumab } \\
\quad(n=8) 62.5 \%\end{array}$ \\
\hline Nosaki, 2019 [35] & $\begin{array}{l}\text { Patients aged } \geq 75 \text { years } \\
\text { Pooled analysis } \\
\text { Pembrolizumab } N=149 \\
\text { Chemo } N=105\end{array}$ & NSCLC & Pembrolizumab & irAEs & $\begin{array}{l}\text { Any treatment-related } \mathrm{AE} \\
\text { Pembrolizumab: age } \geq 75 \text { years: } \\
68 \%, \text { age }<75 \text { years: } 65 \% \\
\text { Chemo: age } \geq 75 \text { years: } 94 \%, \\
\text { age }<75 \text { years: } 87 \% \\
\text { Grade } 3-5 \text { treatment-related } \\
\text { AE } \\
\text { Pembrolizumab: age } \geq 75 \text { years: } \\
\text { 24\%, age }<75 \text { years: } 17 \% \\
\text { Chemo: age } \geq 75 \text { years: } 61 \%, \\
\text { age }<75 \text { years: } 39 \% \\
\text { irAEs and infusion reactions } \\
\text { Pembrolizumab: age } \geq 75 \text { years: } \\
25 \%, \text { age }<75 \text { years: } 25 \% \\
\text { Chemo: age } \geq 75 \text { years: } 7 \%, \\
\text { age }<75 \text { years: } 6 \%\end{array}$ \\
\hline Spigel, 2017 [37] & $\begin{array}{l}N=1308 \\
520 \text { aged } \geq 70 \text { years } \\
\text { ECOG PS } 2 N=108\end{array}$ & NSCLC & Nivolumab & TRAEs & $\begin{array}{l}\text { Any grade TRAE } \\
\text { Age } \geq 70 \text { years: } 62 \%, \\
\text { age }<70 \text { years: } 59 \% \\
\text { ECOG PS } 2: 46 \%, \text { ECOG PS } \\
0-1: 61 \% \\
\text { Grade 3-4 TRAE } \\
\text { Age } \geq 70 \text { years: } 12 \%, \\
\text { age }<70 \text { years: } 11 \% \\
\text { ECOG PS } 2: 10 \%, \text { ECOG PS } \\
0-1: 12 \% \\
\text { Grade } 5 \text { TRAE } \\
\text { Age } \geq 70 \text { years: }<1 \%, \\
\text { age }<70 \text { years: }<1 \% \\
\text { ECOG PS } 2: 2 \%, \text { ECOG PS } \\
0-1:<1 \%\end{array}$ \\
\hline Herin, 2018 [39] & $\begin{array}{l}N=220 \\
46 \text { aged } \geq 70 \text { years }\end{array}$ & $\begin{array}{l}\text { Bladder } \\
\text { carcinoma } \\
\text { NSCLC } \\
\text { Gastrointes- } \\
\text { tinal cancer } \\
\text { Gynaeco- } \\
\text { logical } \\
\text { cancer } \\
\text { Head and } \\
\text { neck carci- } \\
\text { noma } \\
\text { Breast } \\
\text { cancer } \\
\text { Renal cell } \\
\text { carcinoma }\end{array}$ & $\begin{array}{l}\text { Anti-PD-1/PD-L1 mono- } \\
\text { therapy } \\
\text { Anti-PD-1/PD-L1 + other } \\
\text { immuno- } \\
\text { modulatory monoclonal } \\
\text { antibodies } \\
\text { Anti-PD-1 + targeted } \\
\text { therapy }\end{array}$ & irAEs & $\begin{array}{l}\text { Grade } 1 \text { irAE } \\
\text { Age } \geq 70 \text { years: } 72 \% \\
\text { Age }<70 \text { years: } 48 \% \\
\text { Grade } 2 \text { irAE } \\
\text { Age } \geq 70 \text { years: } 41 \% \\
\text { Age }<70 \text { years: } 20 \% \\
\text { Grade } 3-4 \text { irAE } \\
\text { Age } \geq 70 \text { years: } 22 \% \\
\text { Age }<70 \text { years: } 13 \% \\
\text { Median time before first event } \\
\text { Age } \geq 70 \text { years: } 16 \mathrm{~d} \\
\text { Age }<70 \text { years: } 36 \mathrm{~d}\end{array}$ \\
\hline
\end{tabular}

$A E$ adverse event, Chemo chemotherapy, $d$ days, ECOG PS ECOG performance status, Ipi ipilimumab, $N$ number of included patients, Nivo nivolumab, $N S C L C$ non-small cell lung cancer, $P D-1$ programmed cell death-1, $P D$ - $L 1$ programmed cell death-ligand 1, TRAE treatment-related adverse event 
differences in irAEs, severity of grade 3 or higher, multiple irAEs, need for corticosteroid treatment and types of adverse events when comparing different age groups. However, the data showed a trend to more irAEs of any severity and irAEs grade $\geq 3$ occurring in the age $\geq 75$ years group. The most frequently reported irAEs were skin toxicity, gastrointestinal toxicity and endocrinopathy [44].

Chiarion Sileni et al. reported that patients with melanoma aged over 70 years using ipilimumab had similar rates of adverse events compared to patients aged $\leq 70$ years, $50 \%$ vs. $46 \%$ of any grade and $6 \%$ grade $3-4$. The most frequently reported irAEs in patients aged over 70 years were pruritus, rash, diarrhea, nausea and liver toxicity. The median age in patients aged $>70$ years was 75 years, but with an ECOG performance status of 0 or 1 in $97 \%$ of the patients [45], which was not a representative population in daily practice.

Leroy et al. analysed a retrospective cohort of patients aged over 80 years treated with ipilimumab for melanoma. Only 23 elderly patients were included, with a median age of 82 years. They had Charlson comorbidities scores of $0-3$ and $96 \%$ of the patients had an ECOG performance status $0-1$. In this study, $65 \%$ of elderly patients reported adverse events, with $22 \%$ grade 3 and there was one grade 5 adverse event. Of these patients, $22 \%$ of patients needed corticosteroid treatment, two patients needed additive immunosuppressive therapy, four were hospitalised and three had to discontinue ipilimumab. The grade 3 adverse events reported were hepatitis, colitis, hypophysitis and pneumopathy. The authors concluded that irAEs occur at the same rate in older patients compared to younger patients in this study and compared to previously reported studies [46].

Freeman et al. performed a retrospective analysis of irAEs in a cohort of melanoma patients aged $<65$ years compared to patients aged $>65$ years treated with nivolumab. This analysis showed no significant difference in the incidence of irAEs or the irAE profile between the two age groups. The most commonly reported irAEs were diarrhoea/colitis, rash and vitiligo. However, no data on the ECOG performance status and severity of irAEs were provided [47].

In addition, Betof et al. retrospectively analysed 254 patients receiving anti-PD-1 and/or PD-L1 for metastatic melanoma, including 65 patients aged 65-74 years and 47 patients aged $\geq 75$ years. The incidence of arthritis was significantly higher among patients aged $65-74$ years. Patients aged $\geq 75$ years had a higher incidence of thyroiditis or endrocrine-related toxicity; however, this was not statistically significant. No significant differences in dermatitis, colitis, hepatitis or pneumonitis were reported between the different age groups. The grade of severity of the adverse events was not reported [19].

Wong et al. conducted a retrospective analysis of 91 patients with advanced melanoma treated by anti-PD-1, including patients with an ECOG performance status of 2 and 3. Median age in the different groups was 54-73 years. They showed no statistically significant difference in irAEs between the groups with a low vs. high ECOG performance status. They did show that $81 \%$ of patients in the ECOG $2-3$ group received anti-PD-1 therapy in the last month of life, compared with $46 \%$ in the ECOG $0-1$ group [relative risk (RR) $1.75,95 \%$ CI 1.04-2.56; $p=0.019]$. Ninety percent of the patients in the ECOG 2-3 group were admitted to the hospital in the last month of life, compared with $52 \%$ in the ECOG 0-1 group (RR 1.73, 95\% CI 1.10-2.16, $p=0.009$ ). The ECOG 2-3 group were also more likely to die in an acute hospital setting (62\% vs. $23 \%$. respectively; RR 2.68 , 95\% CI 1.17-6.51; $p=0.016$ ) [48]. All hospitalisation within the last month of life was for the management of disease progression. The only apparent admission for treatmentrelated toxicity was the aforementioned case of the patient with pulmonary infiltrates post-anti-PD1.

Horvat et al. performed a retrospective study in 298 patients with metastatic melanoma treated with ipilimumab, with a median age of 65 years and an ECOG performance status of $0-1$. Discontinuation of treatment because of an irAE was reported in $19 \%$ of patients, most commonly because of diarrhoea and hepatotoxicity. Thirty-five percent of patients required systemic corticosteroid treatment for an irAE and $10 \%$ of all patients required additional systemic immunosuppressive therapy, mostly infliximab [49].

Luciani et al. performed a multicenter retrospective analysis on patients aged $\geq 75$ years with advanced NSCLC treated with anti-PD-1 therapy and showed in 72 patients with a median age of 77 years that irAEs grade 3-4 occurred in $14 \%$ of patients, but the majority of patients had an ECOG status of 0-1 (63\%) [50]. Corral de la Fuente et al. retrospectively analysed 98 patients with advanced NSCLC treated with anti-PD-1 or anti-PD-L1 therapy. The mean age was 62 years and 27 patients $(27.5 \%)$ were aged $\geq 70$ years. They reported $30.6 \%$ irAEs, with no statistically significant difference between the older and younger patients. The grade of severity of the adverse events was not reported [51].

Verzoni et al. conducted a retrospective analysis of 389 patients with previously treated advanced or metastatic renal cell carcinoma treated with nivolumab, including 70 patients (18\%) aged $\geq 75$ years with an ECOG performance status of $0-1$ in $93.6 \%$ of patients. Immune-related adverse events occurred in $20 \%$ of patients, but no age-stratified analyses were performed [52].

Muchnik et al. performed a retrospective study in older patients receiving PD-1 inhibitors for advanced-stage NSCLC. They included 75 patients, with a median age of 74 years and 17 (22.7\%) of the patients were aged $\geq 80$ years. The Charlson Comorbidity Index was $\geq 3$ in 40 (53.3\%) patients and 37 (49.3\%) patients had an ECOG performance status of $\geq 2$. Overall, $37 \%$ of the patients experienced irAEs 
Table 3 Overview of observational studies regarding immune-related adverse events in elderly patients with cancer

\begin{tabular}{|c|c|c|c|c|c|}
\hline $\begin{array}{l}\text { Study (first author, } \\
\text { year) }\end{array}$ & No. of patients & Tumour type & Checkpoint inhibitor & Relevant outcome & Results \\
\hline Sattar, 2018 [44] & $\begin{array}{l}N=78 \\
26(33 \%) \text { aged } \\
65-74 \text { years, } \\
23(30 \%) \\
\text { aged } \geq 75 \text { years }\end{array}$ & $\begin{array}{l}\text { Melanoma } \\
\text { NSCLC } \\
\text { Renal cell carcinoma }\end{array}$ & $\begin{array}{l}\text { Ipilimumab } \\
\text { Nivolumab Pembroli- } \\
\text { zumab }\end{array}$ & irAEs & $\begin{array}{l}41(53 \%) \text { patients with } \\
\text { irAEs, } 12(15 \%) \text { mul- } \\
\text { tiple irAEs } \\
\text { Any grade irAEs } \\
\text { Age }<65 \text { years }(n=29) \text { : } \\
41 \% \\
\text { Age } 65-74 \text { years } \\
(n=26): 58 \% \\
\text { Age } \geq 75 \text { years }(n=23) \text { : } \\
61 \% \\
\text { Grade } \geq 3 \text { irAEs } \\
\text { Age }<65 \text { years }(n=17): \\
29 \% \\
\text { Age } 65-74 \text { years } \\
(n=12): 25 \% \\
\text { Age } \geq 75 \text { years }(n=11): \\
36 \%\end{array}$ \\
\hline $\begin{array}{l}\text { Chiarion Sileni, } 2014 \\
\text { [45] }\end{array}$ & $\begin{array}{c}N=855,193 \text { patients } \\
\text { aged }>70 \text { years }\end{array}$ & Melanoma & Ipilimumab & irAEs & $\begin{array}{l}\text { Any irAE: } \\
\text { age }>70 \text { years: } 50 \% \text {, } \\
\text { age }<70 \text { years } 46 \% \\
\text { Grade } 3-4 \text { irAE: } \\
\text { age }>70 \text { years: } 6 \%, \\
\text { age }<70 \text { years: no } \\
\text { data }\end{array}$ \\
\hline Leroy, 2019 [46] & $\begin{array}{c}N=52,23 \text { patients } \\
\text { aged } \geq 80 \text { years }\end{array}$ & Melanoma & Ipilimumab & $\begin{array}{l}\text { irAEs } \\
\text { Treatment irAEs } \\
\text { Hospitalisation } \\
\text { because of irAEs }\end{array}$ & $\begin{array}{l}\text { Any irAE: } \\
\text { age } \geq 80 \text { years: } 65 \%, \\
\text { age } \leq 80 \text { years: } 52 \% \\
\text { Grade }>3 \text { irAE: } \\
\text { age } \geq 80 \text { years: } 22 \%, \\
\text { age } \leq 80 \text { years: } 19 \% \\
\text { Corticosteroid treat- } \\
\text { ment: age } \geq 80 \text { years: } \\
22 \% \text {, age } \leq 80 \text { years: } \\
19 \% \\
\text { Additive immunosup- } \\
\text { pressive therapy: } \\
\text { age } \geq 80 \text { years: } 9 \%, \\
\text { age } \leq 80 \text { years: } 4 \% \\
\text { Hospitalisation: } \\
\text { age } \geq 80 \text { years: } 22 \%, \\
\text { age } \leq 80 \text { years: } 9 \%\end{array}$ \\
\hline Freeman, 2015 [47] & $\begin{array}{c}N=148,52(35 \%) \\
\text { aged } \geq 65 \text { years }\end{array}$ & Melanoma & Nivolumab & irAEs & $\begin{array}{l}\text { Most common irAEs: } \\
\text { Rash: Age } \geq 65 \text { years: } \\
40.4 \%, \text { age }<65 \text { years: } \\
38.5 \% \\
\text { Diarrhoea: } \\
\text { age } \geq 65 \text { years: } 21.2 \%, \\
\text { age }<65 \text { years: } 30.2 \% \\
\text { Vitiligo: age } \geq 65 \text { years: } \\
7.7 \%, \text { age }<65 \text { years: } \\
10.4 \%\end{array}$ \\
\hline Betof, 2017 [19] & $\begin{array}{l}N=254,65(25.6 \%) \\
\text { aged } 65-74 \text { years, } \\
47(18.5 \%) \\
\text { aged } \geq 75 \text { years }\end{array}$ & Melanoma & $\begin{array}{l}\text { Anti-PD-1 } \\
\text { Anti-PD-L1 }\end{array}$ & irAEs & $\begin{array}{l}110(43.3 \%) \text { irAEs in } \\
\text { all patients } \\
\text { Age } 65-74 \text { years: more } \\
\text { arthritis }(10.8 \%, \\
p=0.02) \\
\text { Age } \geq 75 \text { years trend } \\
\text { to more endocrine } \\
\text { toxicity }\end{array}$ \\
\hline
\end{tabular}


Table 3 (continued)

\begin{tabular}{|c|c|c|c|c|c|}
\hline $\begin{array}{l}\text { Study (first author, } \\
\text { year) }\end{array}$ & No. of patients & Tumour type & Checkpoint inhibitor & Relevant outcome & Results \\
\hline Wong, 2017 [48] & $\begin{array}{l}N=91,64 \% \text { ECOG } \\
\text { PS } 0-1,18 \% \text { ECOG } \\
\text { PS } 2,9 \% \text { ECOG } \\
\text { PS } 3\end{array}$ & Melanoma & Anti-PD-1 & irAEs & $\begin{array}{l}\text { Treatment-related AEs } \\
\text { grade }>3 \text { : } \\
\text { ECOG PS 0-1: } 5 \% \\
\text { ECOG PS 2: } 13 \% \\
\text { ECOG PS: } 30 \% \\
\text { irAEs grade >3: } \\
\text { ECOG PS 0-1: } 15 \% \\
\text { ECOG PS 2: } 0 \% \\
\text { ECOG PS 3: } 0 \%\end{array}$ \\
\hline Horvat, 2015 [49] & $N=298$ & Melanoma & Ipilimumab & $\begin{array}{l}\text { Number of irAEs } \\
\text { Treatment irAEs }\end{array}$ & $\begin{array}{l}254(85 \%) \text { irAE } \\
56(19 \%) \text { treatment } \\
\text { discontinuation } \\
103(35 \%) \text { corticoster- } \\
\text { oid treatment } \\
29(10 \%) \text { anti-TNF } \alpha \\
\text { treatment }\end{array}$ \\
\hline Luciani, 2018 [50] & $\begin{array}{l}\text { Patients } \\
\quad \text { aged } \geq 75 \text { years } \\
N=72\end{array}$ & NSCLC & $\begin{array}{l}\text { Nivolumab } \\
\text { Pembrolizumab }\end{array}$ & irAEs & $\begin{array}{l}9(14 \%) \text { irAEs } \\
4(40 \%) \text { grade } 3-4 \\
\text { irAEs }\end{array}$ \\
\hline $\begin{array}{l}\text { Corral de la Fuente, } \\
2019 \text { [51] }\end{array}$ & $\begin{array}{l}N=98 \\
27 \text { aged } \geq 70 \text { years }\end{array}$ & NSCLC & $\begin{array}{l}\text { Anti-PD-1 } \\
\text { Anti-PD-L1 }\end{array}$ & irAEs & $\begin{array}{l}30.6 \% \text { irAEs } \\
\text { No statistically sig- } \\
\text { nificant differences } \\
\text { between older and } \\
\text { younger patients }\end{array}$ \\
\hline Verzoni, 2019 [52] & $\begin{array}{l}N=389 \\
70 \text { aged } \geq 75 \text { years }\end{array}$ & Renal cell carcinoma & Nivolumab & $\begin{array}{l}\text { drAEs } \\
\text { irAEs } \\
\text { Treatment discontinu- } \\
\quad \text { ation }\end{array}$ & $\begin{array}{l}32 \% \text { any } \mathrm{drAE} \\
7 \% \text { grade } \geq 3 \mathrm{drAE} \\
20 \% \text { any grade irAE } \\
2 \% \text { grade } 3 \text { irAE } \\
<1 \% \text { grade } 4 \text { irAE } \\
7.9 \% \text { treatment discon- } \\
\text { tinuation, of which } \\
45 \% \text { because of irAEs }\end{array}$ \\
\hline Muchnik, 2019 [53] & $\begin{array}{l}\text { Patients } \\
\quad \text { aged } \geq 70 \text { years } \\
N=75 \\
53 \% \text { CCI } \geq 3 \\
49 \% \text { ECOG PS } \geq 2\end{array}$ & NSCLC & $\begin{array}{l}\text { Nivolumab } \\
\text { Pembrolizumab } \\
\text { "Other" }\end{array}$ & $\begin{array}{l}\text { irAEs } \\
\text { Treatment irAEs } \\
\text { Hospitalisation }\end{array}$ & $\begin{array}{l}37 \% \text { of any grade irAE } \\
8 \% \text { grade } \geq 3 \text { irAE } \\
64 \text { patients discontin- } \\
\text { ued treatment, } 15 \% \\
\text { because of irAEs } \\
64 \% \text { of patients with } \\
\text { irAE glucocorticoid } \\
\text { treatment } \\
72 \% \text { hospitalisation } \\
\text { during treatment }\end{array}$ \\
\hline Silva, 2018 [54] & $\begin{array}{l}\text { Patients } \\
\quad \text { aged } \geq 65 \text { years } \\
N=106\end{array}$ & $\begin{array}{l}\text { Lung cancer } \\
\text { Melanoma } \\
\text { Urological cancer } \\
\text { Colorectal cancer }\end{array}$ & $\begin{array}{l}\text { Nivolumab } \\
\text { Pembrolizumab } \\
\text { Ipilimumab } \\
\text { Atezolizumab }\end{array}$ & irAEs & $\begin{array}{l}21 \text { irAEs } \\
5 \text { severe irAEs } \\
\text { Frailty predicted risk to } \\
\text { AE: OR } 3.03(95 \% \text { CI } \\
1.36-6.74 ; p=0.006)\end{array}$ \\
\hline
\end{tabular}

$A E$ adverse event, $C C I$ Charlson Comorbidity Index, $C I$ confidence interval, $d r A E$ drug-related adverse event, ECOG PS ECOG performance status, irAEs immune-related adverse events, $N$ number of included patients, $N S C L C$ non-small cell lung cancer, $O R$ odds ratio, $P D-1$ programmed cell death-1, $P D-L 1$ programmed cell death-ligand $1, T N F$ tumour necrosis factor

of any grade and $8 \%$ were grade $\geq 3$ irAEs. Of these patients, $64 \%$ required treatment with glucocorticoids. The most common irAEs were pneumonitis, thyroiditis (both 12\%), colitis and dermatitis (both 9\%). Moreover, they showed that 64 patients discontinued treatment, $15 \%$ because of irAEs. During treatment, $54(72 \%)$ patients were hospitalised, seven patients because of irAEs. The authors found no significant difference in irAE rates between different age, Charlson Comorbidiy Index or ECOG performance status groups [53].

Finally, Silva et al. performed a retrospective study in 106 elderly patients treated with immune checkpoint inhibitors for solid malignancies, with a mean age of 74.4 years. 
They found a similar irAE profile as previously reported. Remarkably, they found that frailty was the only statistically significant variable associated with the development of adverse events [54].

\subsection{Treatment of Immune-Related Adverse Events in Older Patients}

Because irAEs are caused by an excessive immune response, most of these are treated by withholding the immune checkpoint inhibitor or inducing temporary immunosuppression with oral glucocorticoids or additional immunosuppressants [29]. Most irAEs are mild and can be treated symptomatically [30]. To our knowledge, there are no studies on how to treat irAEs specifically in older patients.

According to the European Society for Medical Oncology (ESMO) guidelines, grade 1 and some grade 2 toxicities are mostly treated by withholding immune checkpoint inhibitors while monitoring symptoms and starting symptomatic or local treatment. Grade 3 and 4 toxicities, and some grade 2, are primarily treated with corticosteroid therapy. In the case of no improvement, other immunosuppressive drugs such as mycophenolate mofetil, infliximab (anti-tumour necrosis factor- $\alpha$ ), tacrolimus, cyclophosphamide or anti-thymocyte globulin are recommended as additional therapy [32].

The use of some symptomatic treatments, such as antihistamines for pruritus or corticosteroids can be considered, but these may induce more extra adverse events in elderly patients, such as mental status disturbance, delirium, sodium and fluid retention, hypertension and worsening of diabetes mellitus [30]. Patients with comorbidities such as diabetes mellitus, congestive heart failure or underlying mood disorders may be at a higher risk for adverse events.

\section{Discussion}

In summary, the current available data show no difference in OS and PFS in older patients compared to younger patients and no major increase in irAE incidence in older patients. These data are mainly based on clinical trials, in which the elderly, especially aged $\geq 75$ years, are underrepresented. There are no studies on how to treat irAEs specifically in older patients.

Most of the previously published immunotherapy trials did not perform any subanalyses in the different age groups. Moreover, because of strict inclusion criteria, only patients with a relatively good performance status and few comorbidities were enrolled in these trials. Hence, older patients with reduced functional reserve, or age-related comorbidities including autoimmune diseases and impaired organ function were excluded. The patients included are therefore not representative for the general older population of patients with cancer, which limits the evidence for treatment with immunotherapy in this population.

Interestingly, some of the subgroup analysis of trial data showed a higher incidence of irAEs and a trend towards early treatment discontinuation and a higher incidence of irAEs requiring treatment with immune-modulating medication in older patients [21,38]. Moreover, Herin et al. showed an increased incidence of grade 1-2 irAEs and early occurrence of irAEs in older patients. This can be of consequence for older patients. For example, immune-related diarrhea may lead to a higher incidence of dehydration, decline in renal function and hospitalisation. Hospitalisation may have a different impact on older patients compared with younger patients. In addition, occurrence of multiple grade 1-2 irAEs may be a reason to discontinue therapy, which thereby hampers the efficacy of treatment.

We highlighted 12 observational studies in more reallife older patients than included in clinical trials, but still mainly patients with a good performance status. Previous clinical trials comparing chemotherapy with immune checkpoint inhibitors showed a higher incidence of chemotherapy-related grade 3-4 adverse events [42, 55], implicating that immune checkpoint inhibitors might be well tolerated by elderly patients. The observational studies we cited overall did not show an increased incidence of irAEs. However, some of the included studies showed a trend of a higher incidence of irAEs in older patients. As these studies were performed retrospectively and included a small number of patient, differences in the number of irAEs might not have been detected owing to bias or a lack of power. Furthermore, Muchnik et al. showed that a large proportion of the patients required treatment with glucocorticoids, discontinued treatment and were hospitalised. Moreover, the study of Wong et al. did show an increase in patients discontinuing therapy and more hospital admissions with increasing performance status. This suggests that the incidence of adverse events could be higher in patients with impaired physical functioning. The study also showed that more patients with a decreased performance status received immune checkpoint blockade therapy in the last month of life and were more likely to die in an acute hospital setting, which emphasises the importance of a more precise selection of patients receiving therapy.

It must be noted that the impact of irAEs in elderly patients may be greater than in younger patients, owing to age-related comorbidities and reduced functional reserve. For example, thyroiditis can result in either hypothyroidism or hyperthyroidism, which might worsen the symptoms of an undiagnosed neurocognitive disorder [33]. Interactions 
of adverse events and comorbidities may be problematic. For example, anticoagulants or anti-aggregants may increase the risk of gastrointestinal haemorrhage in colitis or autoimmune thrombocytopenia [20,30].

There are minimal data on the safety in patients with renal of hepatic insufficiency. In contrast to chemotherapy, efficacy and safety of immune checkpoint inhibitors are thought to be similar in patients with renal or hepatic insufficiency because they are not cleared by the kidneys or liver [29]. Therefore, at the moment no dose adjustment is recommended [30]. In addition, adverse events are mostly not dose dependent, apart from the development of irAEs in patients receiving CTLA-4 inhibitors [56].

In the treatment of irAEs, the additional adverse events induced by corticosteroids or infliximab, as well as the effect of hospitalisation on elderly patients must be taken into consideration. Although long-term glucocorticoid therapy is not frequently needed, it may lead to additional complications, such as osteoporosis, glaucoma, cushingoid phenotype, opportunistic infections and proximal muscle weakness $[29,57]$. Del Castillo et al. performed a retrospective study in 790 patients with advanced melanoma treated with an immune checkpoint blockade, assessing the risk of serious infections. They showed that the major risk factor for development of a serious infection was the use of immunosuppressive agents, including corticosteroids and infliximab (13.5\% risk of serious infection vs. 2\%) [58]. Therefore, the duration of corticosteroid usage should be limited, especially in older patients.

Furthermore, in the case of high-dose corticosteroid treatment, elderly patients are at increased risk of skin atrophy. Extra caution should also be taken when using high-dose corticosteroid treatment in elderly patients with underlying gastritis or undiagnosed peptic ulcer disease [33].

Frail patients are at increased risk of chemotherapy intolerance, postoperative complications and mortality [59]. Selecting frail patients using a geriatric assessment can help personalise treatment decisions. Remarkably, only one of the highlighted studies showed that frailty was associated with the development of adverse events. None of the other studies provided data on comprehensive geriatric assessments and measures of frailty. The ECOG and Karnofsky performance status generally overestimate physical functioning of older patients and as a result, these measurements are not valid to predict treatment toxicity [3]. The International Society of Geriatric Oncology therefore states that geriatric assessment can be valuable in clinical practice for the detection of impairments that were not identified in routine history or physical examination. Furthermore, it has been shown to predict severe treatment-related toxicity [3], and has been associated with survival outcomes [60-62]. Previous studies have shown that when a geriatric assessment is performed, it affects treatment choice and intensity
[60]. The recommendation of the International Society of Geriatric Oncology (SIOG) is to evaluate the following domains: functional status, comorbidity, cognition, mental health status, fatigue, social status and support, nutrition and the presence of geriatric syndromes. However, the expert panel could not recommend one tool over another [2]. The G8 screening tool can help identify frail older patients with cancer requiring geriatric assessment and tailoring of cancer treatment $[63,64]$. However, under-treatment of fit older patients might also be prevented in this manner. The ELDERS study is now comparing elderly patients to nonelderly patients receiving immunotherapy for lung cancer or melanoma, also gathering information about the comorbidity score and a geriatric screening assessment. Gomes et al. presented preliminary results of 32 patients with a minimum of 3 months follow-up. They found no statistically significant correlation between higher comorbidity score or abnormal geriatric assessment and the incidence of irAEs and found no significant negative impact on the global health-related quality of life [65]. Unfortunately, these finding are in a small group of patients with a limited follow-up and the final data are not presented yet. To our knowledge, to date, this is the only study evaluating the role of geriatric assessment in older patients receiving immune checkpoint inhibitors, highlighting the importance of future studies in this field.

Furthermore, traditional therapeutic studies rarely include functionality or quality of life as an endpoint, despite the fact that many older adults prioritise it as an important factor in the decision-making process [66]. The effect of immunotherapy on functional status can be critical for older adults, especially if it affects their ability to live independently. Therefore, more real-life-based data on adverse events and the effects on quality of life or effects on functional status can help in shared treatment decision making [67].

\section{Conclusions}

The clinical trials showed no age-dependent efficacy difference for immune checkpoint inhibitors. Overall, the incidence of treatment toxicity in older patients is higher in chemotherapy than immune therapy and clinical trials showed no major increase in irAE incidence with increasing age. However, in real life, studies in older and more vulnerable patients showed a higher incidence of irAEs, a trend to early treatment discontinuation and more patients requiring treatment with immune-modulating medication. The available observational data are limited. Because the enrolled elderly patients are not representative, further prospective studies should include older patients in a representative real-life population. Furthermore, future studies should include a geriatric assessment to identify which patients will benefit from immune checkpoint inhibitors 
and which patients are at higher risk of irAEs, hospitalisation and functional decline, and therefore might not benefit from immune checkpoint inhibitors.

\section{Compliance with Ethical Standards}

Funding No external funding was used in the preparation of this article.

Conflict of Interest Ellen Kapiteijn is on the advisory board of BMS and Merck. Yara van Holstein, Esther Bastiaannet, Frederiek van den Bos, Johanneke E.A. Portielje and Nienke A. de Glas have no conflicts of interest that are directly relevant to the content of this article.

Open Access This article is distributed under the terms of the Creative Commons Attribution-NonCommercial 4.0 International License (http://creativecommons.org/licenses/by-nc/4.0/), which permits any noncommercial use, distribution, and reproduction in any medium, provided you give appropriate credit to the original author(s) and the source, provide a link to the Creative Commons license, and indicate if changes were made.

\section{References}

1. Kankerregistratie, N. Cijfers over kanker. 2019; Incidentiecijfers melanoom, longkanker, kanker urinewegen]. www.cijfersove rkanker.nl. Accessed 5 Jul 2019.

2. Wildiers H, Heeren P, Puts M, et al. International Society of Geriatric Oncology consensus on geriatric assessment in older patients with cancer. J Clin Oncol. 2014;32(24):2595-603.

3. Hurria A, Togawa K, Mohile SG, et al. Predicting chemotherapy toxicity in older adults with cancer: a prospective multicenter study. J Clin Oncol. 2011;29(25):3457-65.

4. de Glas NA, Kiderlen M, Vandenbroucke JP, et al. Performing survival analyses in the presence of competing risks: a clinical example in older breast cancer patients. J Natl Cancer Inst. 2016;108(5):p.djv366.

5. Wildiers H, Mauer M, Pallis A, et al. End points and trial design in geriatric oncology research: a joint European organisation for research and treatment of cancer: alliance for Clinical Trials in Oncology-International Society of Geriatric Oncology position article. J Clin Oncol. 2013;31(29):3711-8.

6. Elias R, Morales J, Rehman Y, et al. Immune checkpoint inhibitors in older adults. Curr Oncol Rep. 2016;18(8):47.

7. Elias R, Karantanos T, Sira E, et al. Immunotherapy comes of age: immune aging \& checkpoint inhibitors. J Geriatr Oncol. 2017;8(3):229-35.

8. Nishijima TF, Muss HB, Shachar SS, et al. Comparison of efficacy of immune checkpoint inhibitors (ICIs) between younger and older patients: a systematic review and meta-analysis. Cancer Treat Rev. 2016;45:30-7.

9. Larkin J, Chiarion-Sileni V, Gonzalez R, et al. Combined nivolumab and ipilimumab or monotherapy in untreated melanoma. N Engl J Med. 2015;373(1):23-34.

10. Romano E, Kusio-Kobialka M, Foukas PG, et al. Ipilimumabdependent cell-mediated cytotoxicity of regulatory $\mathrm{T}$ cells ex vivo by nonclassical monocytes in melanoma patients. Proc Natl Acad Sci USA. 2015;112(19):6140-5.

11. Hao C, Tian J, Liu H, et al. Efficacy and safety of anti-PD-1 and anti-PD-1 combined with anti-CTLA-4 immunotherapy to advanced melanoma: a systematic review and meta-analysis of randomized controlled trials. Medicine (Baltimore). 2017;96(26):e7325.

12. van den Eertweg FAJ, Aarts M, van den Berkmortel WPJ, et al. Behandeling van het gemetastaseerd melanoom anno. Medische Oncologie. 2016;2016:32-4.

13. Weber J, Mandala M, Del Vecchio M, et al. Adjuvant nivolumab versus ipilimumab in resected stage III or IV melanoma. N Engl J Med. 2017;377(19):1824-35.

14. Eggermont AM, Chiarion-Seleni V, Grob JJ, et al. Prolonged survival in stage III melanoma with ipilimumab adjuvant therapy. N Engl J Med. 2016;375(19):1845-55.

15. Marrone KA, Forde PM. Cancer immunotherapy in older patients. Cancer J. 2017;23(4):219-22.

16. Daste A, Domblides C, Gross-Goupil M, et al. Immune checkpoint inhibitors and elderly people: a review. Eur J Cancer. 2017;82:155-66.

17. Zorginstituus Nederland, Medicijnkosten. http://www.medicijnko sten.nl. Accessed 25 May 2019.

18. Pasquali S, Hadjinicolaou AV, Chiarion Sileni V, et al. Systemic treatments for metastatic cutaneous melanoma. Cochrane Database Syst Rev. 2018;2:CD011123.

19. Betof AS, Nipp RD, Giobbie-Hurder A, et al. Impact of age on outcomes with immunotherapy for patients with melanoma. Oncologist. 2017;22(8):963-71.

20. Bhandari S, Gill AS, Perez CA, et al. Management of immunotherapy toxicities in older adults. Semin Oncol. 2018;45(4):226-31.

21. Friedman CF, Horvat TZ, Minehart J, et al. Efficacy and safety of checkpoint blockade for treatment of advanced melanoma (mel) in patients (pts) age 80 and older (80+). J Clin Oncology. 2016;34(15_Suppl.):10009.

22. Khan M, Lin J, Liao G, et al. Comparative analysis of immune checkpoint inhibitors and chemotherapy in the treatment of advanced non-small cell lung cancer: a meta-analysis of randomized controlled trials. Medicine (Baltimore). 2018;97(33):e11936.

23. Peng M, Li X, Lei G, et al. The efficacy and safety of immune checkpoint inhibitor combination therapy in lung cancer: a systematic review and meta-analysis. Onco Targets Ther. 2018;11:7369-83.

24. US Food and Drug Administration. Atezolizumab for urothelial carcinoma. https://www.fda.gov/drugs/resources-informatio n-approved-drugs/atezolizumab-urothelial-carcinoma. Accessed 5 Jul 2019.

25. Flaig TW, Spiess PE, Agarwal N, et al. NCCN guidelines insights: bladder cancer, version 5.2018. J Natl Compr Canc Netw. 2018;16(9):1041-53.

26. Bellmunt J, de Wit R, Vaughn DJ, et al. Pembrolizumab as secondline therapy for advanced urothelial carcinoma. N Engl J Med. 2017;376(11):1015-26.

27. Lemke EA, Shah AY. Management of advanced bladder cancer: an update. J Adv Pract Oncol. 2018;9(4):410-6.

28. Iacovelli $\mathrm{R}$, Ciccarese $\mathrm{C}$, Bria $\mathrm{E}$, et al. Immunotherapy versus standard of care in metastatic renal cell carcinoma: a systematic review and meta-analysis. Cancer Treat Rev. 2018;70:112-7.

29. Postow MA, Sidlow R, Hellmann MD. Immune-related adverse events associated with immune checkpoint blockade. N Engl J Med. 2018;378(2):158-68.

30. Helissey C, Vicier C, Champiat S. The development of immunotherapy in older adults: new treatments, new toxicities? J Geriatr Oncol. 2016;7(5):325-33.

31. Larkin J, Hodi FS, Wolchok JD. Combined nivolumab and ipilimumab or monotherapy in untreated melanoma. N Engl J Med. 2015;373(13):1270-1.

32. Haanen J, Carbonnel F, Robert C, et al. Management of toxicities from immunotherapy: ESMO clinical practice 
guidelines for diagnosis, treatment and follow-up. Ann Oncol. 2018;29(Suppl._4):iv264-6.

33. Alkharabsheh O, Kannarkatt P, Kannarkatt J, et al. An overview of the toxicities of checkpoint inhibitors in older patients with cancer. J Geriatr Oncol. 2018;9(5):451-8.

34. Merck. Keytruda ${ }^{\circledR}$. 2014; https://www.accessdata.fda.gov/drugs atfda_docs/label/2016/125514s012lbl.pdf. Accessed 5 Jul 2019.

35. Nosaki K, Hosomi Y, Saka H, et al. Safety and efficacy of pembrolizumab (Pembro) monotherapy in elderly patients (Pts) with PD-L1-positive advanced NSCLC: pooled analysis from KEYNOTE-010, -024, and -042. Ann Oncol. 2019;30(Suppl._2).

36. Bristol-Myers-Squibb. Opdivo ${ }^{\circledR}$. 2014. https://www.accessdata .fda.gov/drugsatfda_docs/label/2014/125554lbl.pdf. Accessed 5 Jul 2019.

37. Spigel D, Schwartzberg L, Waterhouse D, et al. Is nivolumab safe and effective in elderly and PS2 patients with non-small cell lung cancer (NSCLC)? Results of CheckMate 153: Topic: IT. J Thorac Oncol. 2017;12(1):S1287-8.

38. Singh H, Kim G, Maher VE, et al. FDA subset analysis of the safety of nivolumab in elderly patients with advanced cancers. J Clin Oncology. 2016;34(15_Suppl.):10010.

39. Herin H, Aspeslagh S, Castanon E, et al. Immunotherapy phase I trials in patients older than 70 years with advanced solid tumours. Eur J Cancer. 2018;95:68-74.

40. Hodi FS, O'Day SJ, McDermott DF, et al. Improved survival with ipilimumab in patients with metastatic melanoma. $\mathrm{N}$ Engl J Med. 2010;363(8):711-23.

41. Wolchok JD, Neyns B, Linette G, et al. Ipilimumab monotherapy in patients with pretreated advanced melanoma: a randomised, double-blind, multicentre, phase 2, dose-ranging study. Lancet Oncol. 2010;11(2):155-64.

42. Brahmer J, Reckamp KL, Baas P, et al. Nivolumab versus docetaxel in advanced squamous-cell non-small-cell lung cancer. N Engl J Med. 2015;373(2):123-35.

43. Weber JS, Hodi FS, Wolchok JD, et al. Safety profile of nivolumab monotherapy: a pooled analysis of patients with advanced melanoma. J Clin Oncol. 2017;35(7):785-92.

44. Sattar J, Kartolo A, Hopman WM, et al. The efficacy and toxicity of immune checkpoint inhibitors in a real-world older patient population. J Geriatr Oncol. 2019;10(3):411-4.

45. Chiarion Sileni V, Pigozzo J, Ascierto PA, et al. Efficacy and safety of ipilimumab in elderly patients with pretreated advanced melanoma treated at Italian centres through the expanded access programme. J Exp Clin Cancer Res. 2014;33:30.

46. Leroy V, Gerard E, Dutriaux C, et al. Adverse events need for hospitalization and systemic immunosuppression in very elderly patients (over 80 years) treated with ipilimumab for metastatic melanoma. Cancer Immunol Immunother. 2019;68(4):545-51.

47. Freeman M, Weber J. Subset analysis of the safety and efficacy of nivolumab in elderly patients with metastatic melanoma. J Immunother Cancer. 2015;3(Suppl. 2):P133.

48. Wong A, Williams M, Milne D, et al. Clinical and palliative care outcomes for patients of poor performance status treated with antiprogrammed death-1 monoclonal antibodies for advanced melanoma. Asia Pac J Clin Oncol. 2017;13(6):385-90.

49. Horvat TZ, Adel NG, Dang TO, et al. Immune-related adverse events, need for systemic immunosuppression, and effects on survival and time to treatment failure in patients with melanoma treated with ipilimumab at Memorial Sloan Kettering Cancer Center. J Clin Oncol. 2015;33(28):3193-8.

50. Luciani A, Toschi L, Fava S, et al. Immunotherapy in elderly patients $(\geq 75$ yrs) with advanced non-small cell lung cancer (NSCLC): a multicenter Italian experience. Ann Oncol. 2018;29(Suppl._8).

51. Corral de la Fuente E, Barquín García A, Saavedra Serrano C, et al. Benefit of immunotherapy (IT) in advanced non-small cell lung cancer (NSCLC) in elderly patients (EP). Ann Oncol. 2019;30(Suppl._2).

52. Verzoni E, Carteni G, Cortesi E, et al. Real-world efficacy and safety of nivolumab in previously-treated metastatic renal cell carcinoma, and association between immune-related adverse events and survival: the Italian expanded access program. J Immunother Cancer. 2019;7(1):99.

53. Muchnik E, Loh KP, Strawderman M, et al. Immune checkpoint inhibitors in real-world treatment of older adults with non-small cell lung cancer. J Am Geriatr Soc. 2019;67(5):905-12.

54. Silva CC, Herchenhorn D. Treating the elderly with immune checkpoint inhibitors: real life experience from a large Brazilian center. J Clin Oncology. 2018;36(15_Suppl.):e15077.

55. Borghaei H, Paz-Ares L, Horn L, et al. Nivolumab versus docetaxel in advanced nonsquamous non-small-cell lung cancer. $\mathrm{N}$ Engl J Med. 2015;373(17):1627-39.

56. Bertrand A, Kostine M, Barnetche $\mathrm{T}$, et al. Immune related adverse events associated with anti-CTLA-4 antibodies: systematic review and meta-analysis. BMC Med. 2015;13:211.

57. Huscher D, Thiele K, Gromnica-Ihle E, et al. Dose-related patterns of glucocorticoid-induced side effects. Ann Rheum Dis. 2009;68(7):1119-24.

58. Del Castillo M, Romero FA, Arguello E, et al. The spectrum of serious infections among patients receiving immune checkpoint blockade for the treatment of melanoma. Clin Infect Dis. 2016;63(11):1490-3.

59. Handforth $\mathrm{C}$, Clegg A, Young $\mathrm{C}$, et al. The prevalence and outcomes of frailty in older cancer patients: a systematic review. Ann Oncol. 2015;26(6):1091-101.

60. Hamaker ME, Te Molder M, Thielen N, et al. The effect of a geriatric evaluation on treatment decisions and outcome for older cancer patients: a systematic review. J Geriatr Oncol. 2018;9(5):430-40.

61. Guerard EJ, Deal AM, Chang Y, et al. Frailty index developed from a cancer-specific geriatric assessment and the association with mortality among older adults with cancer. J Natl Compr Canc Netw. 2017;15(7):894-902.

62. Sakurai M, Karigane D, Kasahara H, et al. Geriatric screening tools predict survival outcomes in older patients with diffuse large B cell lymphoma. Ann Hematol. 2019;98(3):669-78.

63. Soubeyran P, Bellera C, Goyard J, et al. Screening for vulnerability in older cancer patients: the ONCODAGE prospective multicenter cohort study. PLoS One. 2014;9(12):e115060.

64. Liuu E, Canoui-Poitrine F, Tournigand C, et al. Accuracy of the G-8 geriatric-oncology screening tool for identifying vulnerable elderly patients with cancer according to tumour site: the ELCAPA-02 study. J Geriatr Oncol. 2014;5(1):11-9.

65. Gomes F, Woolley S, Califano R, et al. MA 1007 elderly lung cancer patients on immunotherapy: preliminary results from the ELDERS study. J Thorac Oncol. 2017;12(11):S1841-2.

66. Fried TR, Bradley EH, Towle VR, et al. Understanding the treatment preferences of seriously ill patients. N Engl J Med. 2002;346(14):1061-6.

67. Tariman JD, Berry DL, Cochrane B, et al. Physician, patient, and contextual factors affecting treatment decisions in older adults with cancer and models of decision making: a literature review. Oncol Nurs Forum. 2012;39(1):E70-83. 